\title{
PREMIUMS IN STOCK-FOR-STOCK MERGERS AND SOME CONSEQUENCES IN THE LAW OF DIRECTOR FIDUCIARY DUTIES
}

\author{
LAWRENCE A. HAMERMESH ${ }^{\dagger}$
}

\section{INTRODUCTION}

It is well known that acquirers of publicly held corporations usually pay substantial premiums relative to the pre-acquisition market prices of the acquired corporations' shares.' Legal scholars have examined a variety of explanations for this phenomenon, ranging from merger gain sharing to inefficient behavioral motivations." Largely absent from these explanations, however, is any effort to differentiate

${ }^{\dagger}$ Associate Professor, Widener University School of Law. I gratefully acknowledge the important comments and suggestions from Justice Jack B. Jacobs, Vice Chancellor Leo Strine, Jr., John Coates, David Marcus, Edward Rock, Andrew L. Strauss, Bernard Black, Guhan Subramanian, and the other participants in the Symposium on Control Transactions, sponsored by the University of Pennsylvania Law Review and the Institute for Law and Economics. Eric Andersen, Kristen Keefer, Bryan Messick, and Dana Sands provided valuable research assistance, and Daniel S. Hamermesh of the University of Texas supplied invaluable advice and statistical analytical assistance.

${ }^{1}$ The data summarized in Appendix A to this Article reflect the continuing pervasiveness of acquisition premiums in mergers and acquisitions. See also Gregor Andrade et al., New Evidence and Perspectives on Mergers, 15 J. ECON. PERSP. 103, 106 tbl.1 (2001) (stating that the median premium for deals in which both target and acquirer were publicly traded, U.S.-based firms was $37.9 \%$ from 1973-1998).

2 See, e.g., Bernard S. Black, Bidder Overpayment in Takeovers, 41 STAN. L. REv. 597, 624-26 (1989) (describing two reasons why overpayment occurs: managers may be habitually over-optimistic about the target's true value, and they may be ignorant about bidding theory); John C. Coates IV, "Fair Value" as an Avoidable Rule of Corporate Law: Minority Discounts in Conflict Transactions, 147 U. PA. L. REV. 1251, $1273-77$ (1999) (identifying three sources of control premiums: synergy value, expropriation value, and pure control value); Reinier Kraakman, Taking Discounts Seriously: The Implications of "Discounted" Share Prices as an Acquisition Motive, 88 Colum. L. REV. 891, 897-98 (1988) (characterizing two distinct explanations for discounts between securities prices and underlying corporate asset values: the misinvestment hypothesis (investors expect corporate managers to misinvest assets) and the market hypothesis (securities prices are discounted because of endogenous noise created by trading and valuation practices)); Lynn A. Stout, Are Takeover Premiums Really Premiums? Market Price, Fair Value, and Corporate Law, 99 YALE L.J. 1235, 124452 (1990) (distinguishing a model of heterogeneous beliefs positing that investors value stock differently from the traditional homogeneous view captured in the capital asset pricing model, in which investors view stocks as perfect substitutes for one another). 
between premiums paid in transactions in which the "acquirer" purchases the shares of the "target" or "selling" firm for cash, and transactions in which the "target's" shares are converted into shares of the "acquirer." The two types of transactions actually are quite distinct. Elaboration upon the distinction raises concerns about the coherence of the Delaware case law which addresses the standards governing judicial review of the conduct of the target's directors. Consideration of such questions in Part I of this Article leads to my suggestion that the Delaware case law could be rationalized by abandoning the change of control litmus test for enhancing both director duties and judicial scrutiny of director conduct. Delaware law should focus instead on the extent to which unilateral director action in approving mergers impairs the ability of shareholders to approve or disapprove such transactions.

Part II of this Article briefly reviews some of the explanations for the payment of merger premiums and questions the cogency of some of those explanations in light of recent merger data. In particular, the merger gain-sharing explanation appears problematic in light of evidence that premiums in cash and stock-for-stock mergers are nearly identical in magnitude. On the other hand, the data indicate that the existence of acquirer shareholder voting rights significantly (and negatively) affects premium size, reinforcing judicial views about the importance of such rights.

Part III examines whether modification of Delaware doctrine concerning the fiduciary obligations of directors in connection with their approval of mergers is necessary so that it more closely matches the level of intensity of judicial review with both the magnitude of the threat to shareholder interests and the likelihood of unchecked director misbehavior. In particular, Part III suggests that (1) a change of control in a merger should at most be one of several factors, rather than wholly conclusive, in the court's decision whether to apply

${ }^{3}$ The terms "acquirer," "target," and "seller" are functionally ambiguous and often interchangeable, as will be explored later in this Article. See infra note 9 (demonstrating the functional equivalence between alternative deal structures).

${ }^{4}$ But see Andrade et al., supra note 1, at 112 (noting significant inferiority of postmerger returns to acquiring firm shareholders where the acquisition is financed with common stock of the acquirer); SARA B. MOELLER ET AL., DO SHAREHOLDERS OF ACQUIRING FIRMS GAIN FROM ACQUISITIONS? 32 tbl.4 (Nat'l Bureau of Econ. Research, Working Paper No. 9523, 2003) (providing merger announcement abnormal return data for deals with private, public, and subsidiary targets), available at http://www. nber.org/papers/w9523. 
"enhanced scrutiny" in reviewing a transaction; and (2) the actions of disinterested and independent directors in relation to mergers warrant enhanced judicial scrutiny only when they unilaterally and significantly impair shareholder voting rights. Finally, the Article suggests that the similarity between the positions of acquiring firm shareholders and target firm shareholders justifies more similar legislative and judicial treatment of both groups in mergers.

\section{EVAluATING MERGER Gains AND OTHER EXPLANATIONS OF PREMIUMS IN LIGHT OF RECENT MERGER DATA}

\section{A. Traditional Gain-Sharing Explanations of Merger Premiums and Their Application in Cash Versus Stock-for-Stock Acquisitions}

Although there are competing views about which explanations most effectively account for the phenomenon of merger and acquisition premiums, traditional explanations posit that acquiring firms justify payment of such premiums based on gains attributable to the merger in the form of synergies or improved management. ${ }^{6}$ In the case of an acquisition for cash, such traditional explanations offer the comforting appearance of fairness to both the target and acquiring firm's shareholders. Payment of a premium to the target corporation's shareholders is a vehicle for sharing merger gains with target shareholders, who, as a result of the cash-out merger, would have no further equity claim to such gains, and therefore would not otherwise share in them.

5 "Enhanced scrutiny" is the Delaware Supreme Court's term for a form of judicial review in which, to sustain the transaction they have approved, directors must come forward with evidence of the subjective reasonableness of their basis for acting and the objective reasonableness of their action in light of the advantage to be achieved or the threat to be avoided. See Unocal Corp. v. Mesa Petroleum Co., 493 A.2d 946, 955 (Del. 1985) (requiring that the directors "show that they had reasonable grounds for believing that a danger to corporate policy and effectiveness existed because of another person's stock ownership" and that they show the measure adopted is "reasonable in relation to the threat posed" before they are accorded the protection of the business judgment rule); see also Omnicare, Inc. v. NCS Healthcare, Inc., 818 A.2d 914, 935 (Del. 2003) (applying Unocal and its progeny to conclude that deal protection devices adopted by the board of the target corporation were impermissibly "preclusive and coercive"); Paramount Communications Inc. v. QVC Network Inc., 637 A.2d 34, 45 (Del. 1994) (drawing upon standards of judicial review developed and applied to defensive measures in Unocal and to bidding deterrents in Mills Acquisition Co. v. Macmillan, Inc., 559 A.2d 1261, 1287-88 (Del. 1989)).

${ }^{6}$ See Kraakman, supra note 2, at 893-95 (describing "traditional accounts of motives and gains in the acquisitions literature"). 
The case of a stock-for-stock merger, however, is starkly different. In such a transaction, shareholders of both constituent corporations remain shareholders in the continuing combined enterprise. Thus, both groups-acquirer shareholders and target shareholders-are able to participate pro rata in gains arising out of the merger. Therefore, a premium to the target's shareholders cannot be justified, as in a cash acquisition, on the premise that it is the only way to permit those shareholders to share in the gains arising from the merger.?

Indeed, from a mechanical standpoint, it is somewhat arbitrary to characterize either corporation in a stock-for-stock merger as an "acquirer" or a "target." From the shareholders' standpoint, such a merger could be structured to provide that either corporation's shares be issued in the transaction. While we ordinarily see stock-for-stock mergers choreographed so that the smaller firm (measured by income, revenue, or aggregate market capitalization) merges into the larger firm (or with its wholly-owned subsidiary), it is just as possible for the minnow to swallow the whale. On occasion, stock-for-stock mergers are structured just that way, where the larger firm merges into the smaller firm (or its subsidiary), and the smaller firm issues shares in the merger. ${ }^{8}$ From the shareholders' standpoint, it should not matter who swallows whom in terms of formal corporate structure or which corporation's shares are issued in the merger; the sole issue of concern is their proportional ownership of the combined firm. ${ }^{9}$

${ }^{7}$ On the other hand, a premium for target shareholders in a stock-for-stock merger may reflect a wealth transfer from acquirer shareholders to target shareholders, just as such transfers may occur in cash acquisitions.

${ }^{8}$ For example, accounts of the May 2000 merger of Tuboscope Inc. and Varco International, Inc. identify Tuboscope as the acquirer (presumably because Tuboscope was the surviving corporation in the merger), yet Tuboscope's aggregate market capitalization was only eighty percent of Varco's, and Tuboscope's revenues were less than two-thirds of Varco's. See Quality Servs. Co., Weekly Corporate Growth Report, 2000 WL 9522790 (April 3, 2000) (noting that Tuboscope was the acquirer); Tuboscope Inc., Form S-4/A 8-9 (Apr. 25, 2000) (stating that for fiscal year 1999 Tuboscope had revenues of approximately $\$ 385$ million while Varco's revenues were approximately $\$ 593$ million), http://www.sec.gov. Despite the difference in value, the merging companies described the transaction as a "merger of equals." Id. at Annex I, Agreement and Plan of Merger.

${ }^{9}$ For example, suppose Whale Co., with 95 million shares outstanding trading at $\$ 20$ per share ( $\$ 1.9$ billion aggregate market capitalization), was to merge with Minnow Co., with only 10 million shares outstanding trading at $\$ 10$ per share $(\$ 100$ million aggregate market capitalization). Each Minnow Co. share was converted in the merger into 0.5 shares of Whale Co. and Minnow Co. merged either into Whale Co. or with a wholly-owned acquisition subsidiary of Whale Co. While such a structure is quite common, where a smaller corporation merges with a much larger corporation (or its subsidiary), the transaction could easily be inverted and yet still achieve the 
In either case, it is not immediately apparent why either of the combining firms' shares should be issued in the merger at a ratio that confers upon either of their respective shareholders a premium (measured by the market value of the shares to be received relative to the market price of the shares to be converted in the merger). If both groups of shareholders end up with a proportionate share of the continuing enterprise that reflects the pre-transaction ratio of their corporation's market value, one could conclude that, on average, they would share fairly in the value of the combined entity and in the value of merger gains. Of course, it is not asserted that, in each individual case, the ratio of merging corporations' pre-announcement stock prices determines a "correct" economic evaluation of the corporations' relative contributions to the combined entity or to the gains resulting from the merger. One firm's shares, for example, may be traded less actively, may be affected by the presence of a controlling shareholder, or may trade at a discount relative to the other firm's shares for some other reason. Perhaps acquirers (corporations whose shares are issued in stock-for-stock mergers) consistently pay a premium because the share prices of target firms are consistently undervalued. While all these reasons might be plausible, however, there is no systematic reason why either merger constituent should pay such a premium solely to allow the other constituent's shareholders to participate in merger gains.

Thus, if merger gain sharing were a valid explanation for the payment of merger premiums, one would expect to find that premiums in cash acquisitions consistently, and significantly, exceed premiums paid in pure stock-for-stock transactions. Indeed, if gain sharing were the only explanation for merger premiums, on average one would expect to find premiums in cash acquisitions, but not at all in stock-for-stock deals.

same economic result from the shareholders' standpoint. Consider the inverted merger in which each of Whale Co.'s 95 million shares is converted into two shares of Minnow Co., with Whale Co. merging into Minnow Co. or with a wholly-owned acquisition subsidiary of Minnow Co. In either merger structure, the Whale Co. and Minnow Co. shareholders' proportionate interests in the continuing entity are the same, with 95\% of the ongoing corporation's shares owned by the original Whale Co. shareholders, and the remaining 5\% owned by the original Minnow Co. shareholders. Presumably the shareholders of both Whale Co. and Minnow Co. would be indifferent as to the choice between these two alternative structures. In each structure, the Whale and Minnow shareholders have the same proportional ownership of the combined firm (95\% for Whale, $5 \%$ for Minnow) as the firms' pre-merger ratio of aggregate market capitalization. 


\section{B. Evaluating Gain Sharing and Alternative Explanations in Light of Merger Premium Evidence}

The reality, however, is that premiums are paid, routinely, in stockfor-stock mergers by the corporation (almost always the one dubbed the "acquirer") that issues shares in connection with the merger. Data from stock-for-stock mergers in 1999, 2000, 2001, and 2002 reveal a mean premium of approximately $30 \%$, as compared to a mean premium of approximately $36 \%$ paid in cash acquisitions. ${ }^{10}$ The median premium observed in stock-for-stock transactions in these years (28.26\%) was essentially identical to the median observed in all-cash acquisitions $(28.07 \%){ }^{11}$

One must be modest about the significance of these data. They are preliminary and limited, both in sample size and in chronological coverage. Their reflection of a near identical premium size in both cash and stock acquisitions, however, must be at least unsettling to those who would explain premium payments on the basis of merger gain sharing.

If merger gain sharing is unconvincing as an explanation for the payment of premiums in stock-for-stock mergers, what alternative explanations are available? One frequently invoked alternative is the theory that acquiring firms' managers consistently cause their firms to overpay in acquisitions in order to satisfy personal interests, namely, greater compensation and more extensive managerial authority. ${ }^{12}$ This acquirer empire-building theory suggests that factors having no apparent economic justification from the standpoint of the acquiring firm's shareholders contribute significantly to the existence and size of the premium. If supported by the data, this suggestion might

${ }^{10}$ Infra Appendix A tbl.1.

${ }^{11}$ Id. This near equivalence is all the more striking given the difference in tax treatment between cash and stock mergers. Cash acquisitions generally create taxable gain for target shareholders, while stock-for-stock mergers generally do not. See, e.g., SAMUEl C. ThOMPSON, JR., TAXABle AND TAX-FrEe CORPORATE MERgERS, ACQUiSITIONS AND LBO'S 3 (1994) (summarizing how the consideration paid in taxable acquisitions generally consists of cash or debt instruments while acquisitions paid for with a substantial portion of stock by the acquiring corporation may qualify as a taxfree acquisitive reorganization). As a result of this difference in tax treatment, one might expect to see premiums in cash acquisitions to be considerably higher than premiums in stock-for-stock mergers in order to compensate target shareholders for the relatively adverse tax consequences of a cash acquisition.

${ }^{12}$ See, e.g., Black, supra note 2, at 627 (explaining bidder overpayment in part because "[i]ncentives to increase size include managers' desire for greater prestige and visibility, the desire of the chief executive officer to leave a legacy and not be a mere caretaker, and compensation structures that reward growth in sales and profits"). 
explain and corroborate the analyses that question both the economic wisdom of mergers from the standpoint of the acquiring corporation's shareholders and the adequacy of legal checks on actions of the acquiring corporation's directors. ${ }^{13}$ Even more encouraging, the theory could explain why premiums paid in mergers are virtually identical regardless of whether the acquisition currency is cash or stock-since there is no apparent reason why the extent and effect of rent seeking by acquirer managers should differ as between those two types of mergers.

A possible empirical test of this suggestion, however, did not support the idea. The potency of private managerial interests might be measured by the extent to which acquiring firm directors agree to share postmerger control with directors or officers of the target firm. It is at least plausible that the private interests of acquiring firm managers would be attenuated-and premiums would be lower-where acquiring firm directors cede substantial postmerger board representation to target directors and officers. In the stock-for-stock merger data we studied, however, the percentage of postmerger directors who had been directors or officers of the target had essentially no effect on the premium size. ${ }^{14}$ On the other hand, a number of recent studies indicate that favorable treatment of target CEOs corresponds to reduced merger premiums, ${ }^{15}$ thus demonstrating that negotiating

${ }^{13}$ See John C. Coffee, Jr., Regulating the Market for Corporate Control: A Critical Assessment of the Tender Offer's Role in Corporate Governance, 84 COLUM. L. REV. 1145, 126972 (1984) (discussing the potential requirement that the bidder obtain shareholder approval for acquisitions); James A. Fanto, Quasi-Rationality in Action: A Study of Psychological Factors in Merger Decision-Making, 62 OHIO ST. L.J. 1333, 1401 (2001) (concluding that there is a relationship between psychological factors in merger decision making and the decrease in value for shareholders as a result of these transactions, and that both corporate and securities law fail to acknowledge these psychological factors). But cf. MOELLER ET AL., supra note 4, at 18-19, 23 (reviewing evidence that negative returns to acquirers in stock-for-stock mergers may be due to signaling effects in which the stock issuance indicates that the firm has "exhausted internal growth opportunities, so that firm value drops as a result of that signal rather than because of the acquisition").

14 Infra Appendix A tbl.2 (demonstrating the effects of target director representation in the surviving corporation on the size of premiums in stock-for-stock mergers).

${ }^{15}$ See Jay C. Hartzell et al., What's In It For Me? CEOs Whose Firms Are Acquired, REV. FIN. STUD. (forthcoming) (presenting regression estimates that provide some evidence indicating that "target CEOs negotiate lower acquisition premia for their own shareholders in transactions that involve extraordinary personal treatment of the CEO"); Julie Wulf, Do CEOs in Mergers Trade Power for Premium? Evidence from "Mergers of Equals," 20 J.L. ECON. \& ORG. (forthcoming Spring 2004) ("The evidence suggests that [target] CEOs trade power for premium by negotiating shared control in the merged firm in exchange for lower [target] shareholder premiums."), available at http://www. management.wharton.upenn.edu/wulfresearch/Papers/MOE_March_03.pdf. 
incentives for target management, rather than for bidder management, may be an explanation of merger premiums.

A variant of the acquirer empire-building theory might explain merger premiums somewhat less cynically, but perhaps more effectively. Where the acquirer is much larger (as measured by revenues, for example) than the target firm, the exchange ratio in a stock-forstock merger has a much lesser economic significance to shareholders, representatives, and managers of the acquirer. Therefore, acquirer representatives might tend to agree to relatively greater merger premiums than those found in mergers among firms of more equal size. What is a few more shares out of the millions already outstanding? Interestingly, however, in our data, the relationship between the size of merger premium and the relative size of merging firms (measured by the ratio of acquirer revenues to target revenues) was negative. $^{16}$ In mergers in which the acquiring firm's revenues were over five times those of the target, merger premiums were a statistically significant $11.65 \%$ below premiums observed in mergers between companies closer in size. ${ }^{17}$ If this pattern were to be confirmed by more thorough empirical analysis, some alternative explanation for the significance of relative firm size would be needed.

We considered one other factor potentially influencing merger premium size-whether the favorable vote of the acquiring firm's shareholders was required. ${ }^{18}$ The intuitive appeal of this factor is the notion that, if approval by the acquiring firm's shareholder were required, the size of the premium the acquiring firm might be willing to pay will be less, so as to help ensure acquiring firm shareholder approval. Conversely, this constraint on the merger premium would be absent if no such approval were needed. This intuition is supported by the merger data, albeit subject to the general limitations noted earlier. More specifically, the data indicate that, other things being equal, the existence of acquiring firm shareholder voting rights reduces the merger premium by $18.65 \% .^{19}$

16

17 Id

18 Id

19 Infra Appendix A tbl.2. This evidence is not inconsistent with the suggestion that "control, without more, has limited value." Bernard Black \& Reinier Kraakman, Delaware's Takeover Law: The Uncertain Search for Hidden Value, 96 NW. U. L. REV. 521, $536 \mathrm{n} .33$ (2002) (citing a study comparing the values of voting and nonvoting shares in the same firms and explaining the low premium accorded to voting shares). Perhaps that inconsistency is resolved by the fact that the economic significance of collective voting control, however insignificant it might appear in the abstract, is abnormally 
These tentative empirical observations suggest some questions about, and possible refinements to, the Delaware case law on the fiduciary duties of the directors of merging firms, as discussed below.

\section{Potential CONSEQUENCES FOR DELAWARE CASE LAW ON FIDUCIARY RESPONSIBILITIES OF THE DIRECTORS OF MERGING CORPORATIONS}

The pervasive phenomenon of premiums in stock-for-stock mergers, and their near equivalence to premiums paid in cash acquisitions, challenges significant elements of established corporate law in the area of mergers and acquisitions-most notably in the area of judicial scrutiny of the conduct of directors. Appreciating the significance of these challenges requires a brief review of some of those legal elements.

The Delaware Supreme Court established two key propositions of law in 1994 in Paramount Communications Inc. v. QVC Network Inc. ${ }^{20}$ and Amold $v$. Society for Savings: ${ }^{21}$ (1) In a transaction (notably a merger) in which control of a corporation is acquired by a single person or group, the directors of the corporation are obliged to obtain the highest current value reasonably available. Their efforts in approving such a transaction are subject to "enhanced scrutiny" by the courts because the stockholders are losing the opportunity to obtain a control premium in the future. ${ }^{22}$ (2) In a transaction (notably a merger) in which control remains in a fluid, disaggregated body of stockholders, the directors have no such obligation to achieve the highest currently available value. Their actions in approving such a transaction (putting aside majority conflict of interest, defensive measures, and/or deal protection devices) are not subject to enhanced judicial scrutiny. ${ }^{23}$

This doctrinal dichotomy, reaffirmed this year by the Delaware Supreme Court, ${ }^{24}$ is appealing in several respects. First, the aspect of the QVC doctrine-insisting upon the realization of the highest current value available when corporate control is acquired for

high precisely where it emerges in a concrete context-as a prerequisite to the accomplishment of a transaction such as an impending merger.

${ }_{20}^{20}$ QV, 637 A.2d 34 (Del. 1994).

21 Armold, 650 A.2d 1270 (Del. 1994).

${ }^{22} Q V C, 637$ A.2d at $43,45$.

23 Arnold, 650 A.2d at $1289-90$.

${ }^{24}$ See Omnicare, Inc. v. NCS Healthcare, Inc., 818 A.2d 914, 927-31 (Del. 2003) (holding that the standard of review to be applied to a decision by a board of directors depends on whether the merger transaction creates a change in control). 
cash-flows logically from traditional merger gain-sharing explanations of premiums. Under those explanations, it makes inherent sense-and Delaware case law requires ${ }^{25}$ - that fiduciaries for target shareholders can, and should, bargain for payment of a premium in a cash acquisition. Therefore, the target shareholders can, to some extent, share in merger gains, along with the acquirer's shareholders, who will enjoy the equity interest in the postmerger enterprise. Second, $Q V C$ 's application of current value-maximization duties, even in stock-for-stock mergers, where postmerger control will be concentrated in the hands of a single shareholder or shareholder group, usefully responds to the empirical observation noted above that collective, but disaggregated, shareholder voting power has considerable value. Thus, shareholder voting power deserves both protection by directors and compensation in the form of a premium. ${ }^{26}$

Third, while there are some complexities at the margin, ${ }^{27}$ the doctrinal dichotomy established in the Delaware case law is relatively easy to apply. It affords the courts a means to review at least some categories of transactions having enormous importance to shareholders. It also allows the courts to defer to the good faith decisions of disinterested directors in transactions (such as most stock-for-stock mergers) in which the target firm's shareholders will in the aggregate retain control of the enterprise and, in any event, will have a controlling vote on whether the transaction goes forward.

${ }^{25} \mathrm{See} Q V C, 637 \mathrm{~A} .2 \mathrm{~d}$ at 44 ("In the sale of control context, the directors must focus on one primary objective-to secure the transaction offering the best value reasonably available for the stockholders-and they must exercise their fiduciary duties to further that end."); Revlon, Inc. v. MacAndrews \& Forbes Holdings, Inc., 506 A.2d 173, 182 (Del. 1986) (discussing the board's responsibility of maximization of the company's value at a sale for the stockholders' benefit); Smith v. Van Gorkom, 488 A.2d 858, 873 (Del. 1985) ("In the specific context of a proposed merger of domestic corporations, a director has a duty ... to act in an informed and deliberate manner in determining whether to approve an agreement of merger before submitting the proposal to the stockholders.").

${ }^{26}$ QVC, 637 A.2d at 42-43; see supra note 19 (discussing the economic significance of collective voting control in the context of a merger).

${ }^{27}$ See In re Santa Fe Pac. Corp. S'holder Litig., 669 A.2d 59, 70-71 (Del. 1995) (holding that a transaction in which thirty-three percent of the company's shares were acquired for cash was not subject to Revlon duties- the duties of a board of directors, once they have decided to sell control of the company, to gain the best available price for the shareholders of that company); $c f$. In re Lukens Inc. S'holders Litig., 757 A.2d 720,732 n.25 (Del. Ch. 1999) (suggesting that a merger in which consideration consisted of sixty-two percent cash and thirty-eight percent stock of the acquirer would likely be subject to Revlon duties). 
Finally, it has also been suggested that the dichotomy usefully identifies when directors of the seller are obliged to seek and obtain maximum current value, as opposed to being permitted a wider range of judgment about longer-term strategic considerations. ${ }^{28}$

For a number of reasons described below, however, there are unsatisfying aspects of the doctrinal emphasis on a distinction between mergers in which corporate control is transferred and those in which it is not. ${ }^{29}$ As described below, the Delaware doctrine could have developed-and could still develop-in a different way, one that might more accurately account for the legislative facts ${ }^{30}$ that inform the development of the doctrine and continue to put pressure on it. What follows, then, is an effort to articulate a doctrinal framework for director duties in mergers that 1 ) rejects a rigid application of the controlshifting test originally articulated in $Q V C$, and 2) substitutes guides for judicial review and director conduct that more accurately address competing interests in mergers. Inspiring this effort is the wise counsel that, "because standards of review serve important policy functions, to formulate or apply those standards without being sufficiently mindful of those functions, risks creating unintended distortions of incentives to the detriment of stockholders." ${ }^{31}$

\section{A. The (Un)importance of Change in Control in Establishing Director Duties and Standards of Judicial Review}

As previously noted, QVC correctly recognized that disaggregated collective voting power over fundamental corporate changes has substantial value and that shareholders should not be deprived of that

${ }^{28}$ See Leo E. Strine, Jr., Categorical Confusion: Deal Protection Measures in Stock-forStock Merger Agreements, 56 BUS. LAW. 919, 931 (2001) (explaining that the QVC change of control test highlights when corporate directors are obliged to work for the greatest immediate value).

${ }^{29}$ This is not the first expression of dissatisfaction with this doctrinal dichotomy. See Black \& Kraakman, supra note 19, at 534-37 (arguing against the disparate treatment of change of control transactions). In fact, Black and Kraakman, as well as Marcel Kahan, have previously addressed many of the points made in this Article with respect to the law of mergers and acquisitions. Id. at 534-36, 544, 546-47; Marcel Kahan, Paramount or Paradox: The Delaware Supreme Court's Takeover Jurisprudence, 19 J. CORP. L. 583, 593-99 (1994). Appendix B compares the recommendations in this Article with those in the articles by Black \& Kraakman and Kahan. Infra Appendix B.

${ }^{30}$ See Leo E. Strine, Jr., The Inescapably Empirical Foundation of the Common Law of Corporations, 27 DEL. J. CORP. L. 499, 503 (2002) (describing the role of "legislative facts" in guiding the development of corporate common law).

${ }^{31}$ William T. Allen et al., Function Over Form: A Reassessment of Standards of Review in Delaware Comporation Law, 56 Bus. LAw. 1287, 1297 (2001). 
value without compensation. ${ }^{32}$ It is thus difficult to quarrel with the court's observation that "[o]nce control has shifted, the current... stockholders will have no leverage in the future to demand another control premium. As a result, [they should receive] a control premium and/or protective devices of significant value." $Q V C$ also correctly concluded that the loss of such collective voting power in an acquisition of corporate control may be significant in establishing the substantive fiduciary obligations of target directors and the way in which courts should evaluate their conduct in light of those obligations. ${ }^{34}$

It is quite another thing, however, to posit that the transfer of corporate control invariably triggers a duty to achieve maximum current value and requires enhanced judicial scrutiny, while the absence of such a transfer of control invariably does neither. ${ }^{35}$ The questionable aspect of $Q V C$ is its holding that the passage of control and the concomitant loss of voting power always mandate enhanced judicial scrutiny. ${ }^{36}$

The Delaware Supreme Court, moreover, has established an equally questionable premise with respect to mergers which do not involve a change of control. In Arnold, the Delaware Supreme Court reasoned that in such non-change of control mergers the "plaintiff's opportunity to receive a control premium is not foreclosed. Thus, plaintiff's claim that enhanced scrutiny is required under the circumstances of this case lacks merit ...." ${ }^{37}$ In other words, as long as control does not pass in a merger, enhanced scrutiny is not required and the directors' approval of the transaction is entitled to judicial deference under the business judgment rule.

This bifurcated approach to judicial review is subject to critique on both sides. First, it must surely be an overstatement that all

${ }^{32}$ Supra text accompanying note 26.

${ }^{33}$ Paramount Communications Inc. v. QVC Network Inc., 637 A.2d 34, 43 (Del. 1994). The only disputable point is the extent of such value. See Black \& Kraakman, supra note 19, at 522-23 (outlining the hidden value model of the stock market).

${ }^{34} 637$ A.2d at $43-44$.

${ }^{35}$ Vice Chancellor Strine similarly questioned the bifurcated structure of Delaware merger doctrine. His work suggests that judicial deference may be appropriate with regard to the directors' decision to approve a stock-for-stock merger, but that such deference may not be equally appropriate for deal protection devices associated with that merger. See Strine, supra note 28, at 931 (arguing that the use of the QVC test in this manner lacks judicial precedent and produces "odd" results).

${ }^{36} 637$ A.2d at 45 (explaining why enhanced judicial scrutiny is necessary in change of control transactions).

Arnold v. Soc'y for Sav., 650 A.2d 1270, 1290 (Del. 1994). 
mergers involving a change of control should be subjected to enhanced judicial scrutiny. Although these transactions are undeniably important to shareholder interests, their formal legal prerequisites already protect shareholder interests (at least "target" firm shareholder interests) to a relatively unusual extent: not only must the full board of directors approve the transaction, but so too must the holders of a majority of the outstanding shares of stock. ${ }^{38}$ Thus, there are legitimate questions as to why a plaintiff stockholder should be entitled to insist upon enhanced judicial scrutiny of a cash acquisition involving a change of control when the transaction is the product of disinterested and independent director approval and cannot take place without the approval of a majority of the outstanding voting shares, voting in an uncoerced setting. ${ }^{39}$ Such a context, with unfettered approval by both disinterested, independent directors and disinterested shareholders would seemingly eliminate any suspicion of the conduct of the directors or, at least, would restore the level of judicial deference associated with the business judgment rule. ${ }^{40}$ A more intrusive level of judicial involvement undervalues the significance of the shareholder franchise and the ability of shareholders to make effective voting choices as to issues affecting their financial interests-even a decision to approve a merger in which they collectively cede their aggregate control of the corporation. ${ }^{41}$

${ }^{38}$ See, e.g., DEL. CODE ANN. tit. 8, § 251 (b)-(c) (2001) (requiring board and shareholder approval for merger agreements); infra text accompanying notes 100-05 (discussing the anomaly of requiring enhanced judicial scrutiny in the situation of a change of control approved by disinterested directors and shareholders, while affording no such scrutiny to the actions of the directors of the acquirer in approving an acquisition-a matter on which the acquirer shareholders generally have no voting right at all, at least in a cash acquisition).

${ }^{39}$ See Kahan, supra note 29, at 596 (questioning why Revlon duties or enhanced judicial scrutiny need exist at all where shareholders have an uncoerced voting choice and can reject a board-approved merger without cost); Paul L. Regan, The Unimportance of Being Earnest: Paramount Rewrites the Rules for Enhanced Scrutiny in Corporate Takeovers, 46 HASTINGS L.J. 125, 129 (1994) ("[T] he undisputed significance of a change-ofcontrol transaction is, without more, an insufficient doctrinal basis to displace the deference otherwise accorded to decisions made in good faith by informed and disinterested directors, even in the context of a corporate takeover.").

${ }^{40}$ Delaware case law has long established that "where a majority of fully informed stockholders ratify action of even interested directors, an attack on the ratified transaction normally must fail." Gerlach v. Gillam, 139 A.2d 591, 593 (Del. Ch. 1958); see also Gottlieb v. Heyden Chem. Corp., 91 A.2d 57, 59 (Del. 1952) (explaining that a "new set of rules" is invoked when a majority of independent and fully informed stockholders gives its approval).

${ }^{41}$ See Allen et al., supra note 31, at 1308-09 (arguing in favor of applying the business judgment rule to "self-interested mergers that are approved by either an effective 
In contrast, when evaluating mergers in which control does not pass, it is equally unclear why the shareholder interests at stake do not justify judicial review more searching than that afforded under the business judgment rule, at least on some occasions. Since (as observed above) premiums paid in mergers that do not shift control are routinely equivalent in size to those in mergers that do shift control, ${ }^{42}$ why should such premiums not be as important a doctrinal consideration as the premiums paid when control changes? Should they not have similar legal consequences?

The answer that QVC seems to supply is that target firm shareholders in stock-for-stock mergers may receive shares that can elicit a control premium in the future, but shareholders receiving cash for their shares in a control sale do not. This answer, however, overlooks the possibility that shareholders receiving cash for their shares in a control-shifting merger can achieve essentially the same position obtained through a stock-for-stock merger. They can do this by simply taking their cash and investing it in other public company shares that still retain the potential to elicit a control premium in the future. QVC's answer also overlooks the point that shareholders who become minority shareholders following a merger (as in QVC itself) do not inevitably and irrevocably lose the opportunity to obtain a premium for their shares. There are numerous instances, some documented in Delaware case law itself, in which companies with a controlling stockholder are sold, and both controlling and minority stockholders receive the same premium for their shares. ${ }^{43}$ In short, the loss of a future premium seems to be neither a terribly dramatic consequence nor an inevitability, even after a stock-for-stock merger in which control passes.

On the other hand, stock-for-stock exchange ratios that are disproportionately weighted to one side's shareholders transfer wealth from one set to the other and threaten at least as much potential

independent director committee or by a majority of the minority stockholder vote"); see also Black \& Kraakman, supra note 19, at 560 ("[A] shareholder voting decision, to endorse or veto the target board's decision, is far better than unfettered board discretion, and can usually block a truly bad board decision.").

${ }^{42}$ See supra text accompanying notes 10-11.

${ }^{43}$ See, e.g., Omnicare, Inc. v. NCS Healthcare, Inc., 818 A.2d 914, 918 (Del. 2003) (reviewing a bidding war involving competing cash and stock bids with identical terms for both Class A and Class B common stock, where two directors owned a majority of the voting power through their ownership of the high-vote Class B stock); McMullin v. Beran, 765 A.2d 910, 915-16 (Del. 2000) (discussing the sale of a majority-owned subsidiary in which all shares received the same purchase price). 
harm to target shareholder economic interests as the loss of the potential future realization of a premium in the target firm's shares. What comfort is it to shareholders to receive publicly traded shares of the acquiring corporation, having a value greater than the pre-existing market price of their shares, where the directors have squandered an opportunity to obtain a substantially greater premium? In other words, the problem that QVC identifies may not really be the loss of an opportunity to obtain a premium in the future, but rather the failure to achieve the maximum premium available for the shares at the time of the merger itself.

If the real driving force of $Q V C$ 's doctrine is the lost (or insufficiently exploited) opportunity to obtain a premium that arises when a sale of control occurs, rather than the supposed loss of an opportunity to obtain a premium in the future, it is unclear why legal doctrine must deal in a starkly different, even opposite way, with the potential for a lost or insufficiently exploited opportunity to obtain the kind of premium commonly paid in a stock-for-stock merger in which control does not pass. ${ }^{45}$ This is not to argue, of course, either that director action in all mergers must be subjected to enhanced judicial scrutiny, or that all mergers impose a duty upon directors to obtain the highest current value available for the stockholders. ${ }^{46}$ The point here is simply

${ }^{44}$ See Strine, supra note 28 , at 930 (discussing problems associated with unfair exchange ratios); see also Black \& Kraakman, supra note 19, at 536 (discussing the parallel potential problems in both a sale of control and a stock-for-stock merger).

${ }^{45}$ Perhaps the change of control aspect of $Q V C$ was, ultimately, not terribly important. Consider, for example, how the court might have reacted if the Paramount/Viacom merger agreement had not been shored up by deal protection measures at all. See Paramount Communications Inc. v. QVC Network Inc., 637 A.2d 34, 4950 (Del. 1994) (discussing the prominent role played by the defensive measures of Paramount's board in the court's conclusion that the directors' actions were "not reasonable"). In that circumstance, the Paramount stockholders would have had the unfettered ability to vote the deal up or down in relatively short order. See id. at 42-43 (implying that public shareholders owned the majority of Paramount's voting shares, and that, absent the protective measures imposed by the board, the shareholders could have voted against the deal). Would the court really have brought enhanced scrutiny to bear upon a transaction that the stockholders were quite free to approve or prevent, even if it would have resulted in a change of control? Perhaps the court in $Q V C$, rather than relying on the change of control aspect of the transaction, should have singled out the deal protection measures in that case as the source of the need for enhanced judicial scrutiny. Had the court done so, rather than focus on the change of control as the source of enhanced judicial scrutiny, some degree of "categorical confusion" in this doctrinal field might have been avoided. See Strine, supra note 28 , at $926-31$ (discussing the problems of basing enhanced judicial scrutiny on the change of control test).

${ }^{46}$ Cf. Black \& Kraakman, supra note 19, at 536 (urging that target directors face "a strong conflict of interest" in approving any merger, and if such conflicts "justify 
that a more coherent set of triggers for application of these doctrinal approaches may be necessary.

\section{B. Is the Beauty of Revlon Only Skin Deep?}

Before revisiting the subject of triggers, however, we should pause to clarify what we are concerned about triggering. In this regard, ever since the Delaware Supreme Court's 1986 landmark opinion in Revlon, Inc. v. MacAndrews $\mathcal{E}$ Forbes Holdings, Inc., ${ }^{47}$ the law governing directors' duties in mergers has been fragmented in a respect that parallels the dichotomy described and criticized in the preceding Section. Revlon has two principal doctrinal offshoots. First, where a company is to be sold (whatever that means), the directors' duties "change[d] from defenders of the corporate bastion to auctioneers charged with getting the best price for the stockholders." few years later by the Delaware Supreme Court, Revlon also establishes that the activation of those duties triggers "enhanced judicial scrutiny" of the sort (and in the framework) that would be applied if the directors had unilaterally approved some defensive measure. ${ }^{49}$ The latter proposition is hardly stunning: after all, in Revlon, every step the defendant directors took occurred in response to repeated, unsolicited (and, in some respects, genuinely hostile) efforts to acquire control of the company. ${ }^{50}$ Moreover, the steps principally at issue in the case were deal protection measures of enormous, perhaps even "draconian," proportions. ${ }^{\text {.I }}$ It would have been surprising indeed for the

special scrutiny in sales of control, they justify similar scrutiny in stock-for-stock mergers"). While generally agreeing with the logic of Black and Kraakman's argument, this Article argues, instead, that the existence of such conflicts is not self-evident, and, especially in light of the legitimizing influence of uncoerced approval by disinterested shareholders, not all mergers involving a transfer of control should give rise to special scrutiny. Black and Kraakman also suggest that special judicial scrutiny is appropriate at least where the acquirer is substantially larger than the target, such that the acquirer issues less than twenty percent of its shares in the merger and, thus, offers little prospect of substantial "hidden value." Id. at 544 . This choice, however, may be backwards. In light of the data indicating that premiums are substantially lower where acquirer shareholders vote on the merger (e.g., where more than twenty percent of the acquirer's shares are issued), one could argue that target shareholders ought to have greater, not lesser, protection from (and fiduciary demands upon) their directors where the acquirer's shareholders vote on the merger.

47506 A.2d 173 (Del. 1986).

${ }^{48} I d$. at 182.

49 See $Q V C, 637$ A.2d at 45 (describing the alteration of directors' duties in the case where sale of the company was inevitable); id. at 184 (same).

${ }^{50}$ Revlon, 506 A.2d at 177-79.

${ }^{51}$ Id. at 180. 
court, so soon after its decision in Unocal Corp. v. Mesa Petroleum Co., ${ }^{52}$ to have applied any standard of review to the Revlon directors' actions other than enhanced scrutiny. ${ }^{53}$

The more inscrutable offspring of Revlon-and the source of unnecessary doctrinal schism-is its ostensible reconfiguration of director duties in the context of a "sale" of the company." Apart from the difficulties and confusion surrounding what a "sale" is and when that reconfiguration of duties occurs, ${ }^{55}$ is the even subtler question of what that reconfiguration actually means when it does occur. This question needs to be answered as part of any exercise in understanding the framework of fiduciary duties applicable to cash acquisitions, as opposed to stock-for-stock mergers. The thesis that follows in this Section is that Revlon's ostensible reconfiguration of director duties in certain mergers is only skin deep and should not be allowed either to overstate the responsibilities of directors and the courts in change of control transactions, or to obscure or minimize their roles in ordinary stock-for-stock mergers. ${ }^{56}$

As previously noted, we know from Revlon and QVC that, in a change of control transaction, the directors have a duty to obtain for the shareholders the highest value reasonably available. ${ }^{57}$ But does this concept have any specific content? At the most basic level the concept borders on the vacuous: it merely holds that, in choosing between competing cash bids, directors must choose the higher bid, all

${ }^{52} 493$ A.2d 946 (Del. 1985).

${ }^{53} I d$. at 955 (stating that the power of the directors to protect their corporation is limited, and " $[\mathrm{a}]$ corporation does not have unbridled discretion to defeat any perceived threat by any Draconian means available").

${ }^{54}$ See Reulon, 506 A.2d 173, 182.

55 See, e.g., Ronald J. Gilson \& Reinier Kraakman, What Triggers Revlon ?, 25 WAKE FOREST L. REV. 37, 38 (1990) ("Revlon ties management's obligations during a takeover attempt to a discrete event-the point at which a sale of the company becomes inevitable-that is both ambiguous and commonplace, since its occurrence may be difficult to pinpoint in a hostile takeover, and, yet, it must arise in every friendly acquisition." (footnote omitted))

${ }^{56}$ Moreover, to the extent that Revlon duties lose their talismanic significance, it may, and should, become less important to spend doctrinal effort worrying about when those duties arise. But see Allen et al., supra note 31, at 1321 n.130 (emphasizing the continued importance of determining when Revlon duties apply).

${ }^{57}$ See text accompanying notes 22, 48; see also Leo E. Strine, Jr., The Social Responsibility of Boards of Directors and Stockholders in Change of Control Transactions: Is There Any "There" There?, 75 S. CAL. L. REV. 1169, 1175-76 (2002) ("[T] he board is charged with getting the highest immediate value in the deal ... [where] the board's singular focus is on getting the best price for the current stockholders, regardless of the interests of other constituencies."). 
other things being equal. ${ }^{58}$ That proposition seems unassailable. As Black and Kraakman have pointed out, however, things never are equal: directors' duties in evaluating competing bids should not prevent them, even where the competing bids are in cash, from looking beyond nominal offered values and considering other factors, like financial and regulatory risks. ${ }^{59}$ All that $Q V C$ requires, even when applying Revlon, is that the directors try to "achieve an objective comparison of the alternatives" it will be received by the stockholders." ${ }^{, 1}$ Even in this comparison of value, however, the court acknowledged that there was room for director judgment and discretion in evaluating competing bids permitting them to take into account strategic considerations beyond nominal price. ${ }^{62}$ Presumably, judicial flexibility even permits directors to take into account potential effects on nonshareholder constituencies, at least to the extent that such effects potentially influence the value of the bids under consideration and are, therefore, "rationally related [to] benefits accruing to the stockholders."

Does the law really require any less of directors faced with competing stock bids, neither of which would involve a change of control? In that situation, does the law allow the directors to accept a bid that the directors believe to involve (or offer) substantially less value at the time? One suspects not. Any other view of the law would be hard, indeed, to reconcile with the consensus (extensively debated, to be sure) that the function of the corporation, and those who manage it, is to enhance corporate profit and shareholder gain. ${ }^{64}$ One suspects, rather, that, in such a case, the directors would merely claim that their

${ }^{58}$ Paramount Communications Inc. v. QVC Network Inc., 637 A.2d 34, 44 (Del. 1994) (holding that although the board of directors needs to look at a variety of factors, the board still has one "primary objective-to secure the transaction offering the best value reasonably available for the stockholder").

${ }^{59}$ See Black \& Kraakman, supra note 19, at 539 (discussing the type of discretion a board should retain in determining maximum value).

${ }^{60}$ QVC, 637 A.2d at 44.

${ }^{61}$ Id. at 44 n. 14 .

${ }^{62} I d$. at 44.

${ }^{63}$ Revlon, Inc. v. MacAndrews \& Forbes Holdings, Inc. 506 A.2d 173, 182 (Del. 1986).

${ }^{64}$ See Am. Law InST., Principles of Corporate Governance: ANAlysis and RECOMMENDATIONS $\$ 2.01$ (a) (1994) ("[A] corporation should have as its objective the conduct of business activities with a view to enhancing corporate profit and shareholder gain."); E. Norman Veasey, Should Corporation Law Inform Aspirations for Good Corporate Governance Practices-Or Vice Versa?, 149 U. PA. L. REV. 2179, 2184 (2001) ("Our jurisprudence is full of the rubric that directors should act in the honest belief that the action taken is in the best interests of the corporation and its shareholders."). 
judgments about long-range, intangible prospects for success (including how effects on other constituencies are likely to translate into shareholder value) are entitled to greater weight than identification of which bidder is prepared to pay a greater sum in cash.

Perhaps, one might argue, the significance of Revlon and QVC lies in some obligation on the part of directors to explore alternatives more thoroughly when a proposed merger involves a change of control. If a heightened duty to explore alternatives is, indeed, part of a director's Revlon duties, it too has relatively little specific content as a rule. $^{65}$ Certainly nothing in Revlon requires that directors negotiate with more than one bidder, conduct an active bidding contest, or even conduct an explicit market check. ${ }^{66}$ Thus, despite considerable fixation by the legal community upon Revlon as a separate doctrinal fount, the Delaware Supreme Court itself appropriately described Revlon as "merely one of an unbroken line of cases that seek to prevent the conflicts of interest that arise in the field of mergers and acquisitions by demanding that directors act with scrupulous concern for fairness to shareholders." ${ }^{67}$

Clearly, the real significance of Revlon, $Q V C$, and related Delaware case law is not in reconfiguring the directors' duties, but in determining how the courts should assess the directors' decision that the deal they have approved satisfies the legal mandate to enhance shareholder value. This, of course, is a question of standards of judicial review, and not substantive director duties. Indeed, perhaps all that Revlon and QVC mean is that in change of control mergers, the courts should be less inclined to accept claims that directors chose one bid as superior when a competing bid appeared to have a higher current market value. ${ }^{68}$ This more limited view of Revlon and QVC returns us to the questions of whether a change of control should simply be a binary on-off switch for triggering such enhanced judicial scrutiny, and

${ }^{65}$ See Allen et al., supra note 31 , at 1321 (“[T] he Revlon standard differs little from the Unocal standard in practical application.").

${ }^{66}$ See Barkan v. Amsted Indus., 567 A.2d 1279, 1287 (Del. 1989) ("When ... the directors possess a body of reliable evidence with which to evaluate the fairness of a transaction, they may approve that transaction without conducting an active survey of the market.").

${ }^{67}$ Id. at 1286.

68 This disinclination is what Black and Kraakman urge as a lower judicial tolerance for claims of "hidden value." See Black \& Kraakman, supra note 19, at 539-40 (arguing that judicial deference to directors should lessen as the "importance of hidden value ... shrinks"). 
whether there are more useful alternative approaches for determining when such scrutiny is warranted.

\section{An Alternative Doctrinal Approach to Judicial Evaluation of Target Firm Director Conduct in Mergers}

The analytical framework suggested in this Section is not an attempt to reinvent Delaware corporate law concerning standards of judicial review of director action in the context of mergers. In fact, to some extent, what follows is simply a reminder of two important and salutary aspects of Delaware merger doctrine. Both are wellestablished and should remain so in order to protect shareholder interests against unilateral action by directors or controlling shareholders. Beyond that, this Section merely suggests a third basis for enhanced judicial review-a focus on shareholder voting rights-that is amply supported, and perhaps now fully clarified, in Delaware case law.

First, conflicts of interest on the part of a majority of the directors and a controlling shareholder will subject a merger to the most stringent form of judicial review-in which the proponents of the transaction must establish its "entire fairness" as a matter of both price and procedure. ${ }^{69}$ This is true regardless of whether the merger is a cashout merger or one in which the minority shareholders receive stock of the parent company. After all, the leading Delaware case that established the principle of "entire fairness" review in controlled mergers over fifty years ago was a stock-for-stock transaction in which control did not shift. ${ }^{70}$ Whether, in such mergers, uncoerced, disinterested shareholder approval alone should eliminate enhanced judicial scrutiny altogether is a matter of continuing debate. Some corporate law scholars urge that it should ${ }^{71}$ and that shareholder approval shifts the burden of proof to those challenging the merger. ${ }^{72}$

${ }^{69}$ See, e.g., Weinberger v. UOP, Inc., 457 A.2d 701, 710 (Del. 1983) (“[W]here one stands on both sides of a transaction, he has the burden of establishing its entire fairness, sufficient to pass the test of careful scrutiny by the courts.").

${ }^{70}$ Sterling v. Mayflower Hotel Corp., 93 A.2d 107, 109-10 (Del. 1952); see also Krasner v. Moffett, 826 A.2d 277, 287 (Del. 2003) (remanding for possible application of "entire fairness" review to a stock-for-stock merger approved by a potentially conflicted majority of directors, but not involving a change of control).

${ }^{71}$ See Allen et al., supra note 31, at 1308-09 (noting that the argument that even fully informed, disinterested shareholder approval may be coerced is unsubstantiated and, therefore, does not justify enhanced scrutiny).

${ }^{72}$ See, e.g., Kahn v. Lynch Communications Sys., Inc., 638 A.2d 1110, 1117 (Del. 1994) (shifting the burden to the challenging shareholder to prove unfairness if the 
Second, and similarly, director actions approving unsolicited takeover bids have elicited some degree of enhanced judicial scrutiny, at least since Unocal was decided in 1985 . In fact, the whole concept of enhanced scrutiny or intermediate levels of judicial review of mergers arose in cases in which directors entered into merger agreements in response to hostile bids. ${ }^{73}$ Moreover, application of such judicial scrutiny occurred regardless of whether the merger in question was a cash merger or a stock-for-stock merger in which control did not change. ${ }^{74}$

The third proposition of Delaware law relevant to determining the duty of directors in approving a merger rests on the recognition that in the field of mergers, unlike most other business decisions, by statute directors must share corporate power with shareholders. ${ }^{75}$ While the shareholders cannot unilaterally initiate or approve mergers, their vote is necessary to effectuate the transaction. ${ }^{76}$ The right of shareholders to vote on a merger is an important one, as the empirical data reviewed earlier illustrate. ${ }^{77}$ Accordingly, Delaware case law has, at least ostensibly, sought to protect that right against impairment by unilateral director action. ${ }^{78}$

transaction is approved by an informed majority of minority shareholders).

${ }^{73}$ See, e.g., Paramount Communications, Inc. v. Time, Inc., 571 A.2d 1140, 1151-55 (Del. 1990) (applying the Unocal standard to Time's response to Paramount's hostile tender offer); Mills Acquisition Co. v. Macmillan, Inc., 559 A.2d 1261, 1279 (Del. 1988) (noting that where a self-interested director makes a manipulative and deceptive business decision, the resulting transaction is subject to entire fairness judicial review); Revlon, Inc. v. MacAndrews \& Forbes Holdings, Inc., 506 A.2d 173, 182-84 (Del. 1985) (evaluating the directors' approval of a merger with a "white knight" under Unocal standards).

${ }_{74}$ See, e.g., In re Holly Farms Corp. S'holders Litig., No. 10350, 1988 Del. Ch. LEXIS 164, at *12 (Del. Ch. Dec. 30, 1988) (reviewing an application to enjoin consummation of a stock-for-stock merger in which control would not pass and holding that, " $[\mathrm{b}]$ ecause this sale came in response to, and as an alternative to, Tyson Foods' $\$ 52$ cash tender offer, I agree that the Board's actions must be judged under the standards articulated in Revlon").

${ }^{75}$ DEL. CODE ANN. tit. 8, § 251 (c) (2001).

${ }^{76} I d$.

${ }^{77}$ Supra text accompanying notes 18-19.

78 See, e.g., MM Cos. v. Liquid Audio, Inc., 813 A.2d 1118, 1127 (Del. 2003) ("The [c] ourts of this [s] tate will not allow the wrongful subversion of corporate democracy by manipulation of the corporate machinery or by machinations under the cloak of Delaware law." (quoting Giuricich v. Emtrol Corp., 449 A.2d 232, 239 (Del. 1982))); Frederick H. Alexander, Reining in Good Intentions: Common Law Protections of Voting Rights, 26 DEL. J. CORP. L. 897, 902-03 (2001) (noting that protecting the integrity of stockholders' voting rights guards against draconian deals). 
Thus, this Article argues that Delaware law should apply proportionality standards of review, as developed in Unocal and its progeny, ${ }^{79}$ where director action in connection with a merger materially impairs the ability of shareholders to exercise their right to vote on a proposed merger. In fact, this proposition-that voting impairment should trigger enhanced scrutiny-may already be the law. Even before the recent decision in Omnicare, Inc. v. NCS Healthcare, Inc., this proposition was regularly applied by the Delaware Chancery Court. ${ }^{80}$ In addition, the Delaware Supreme Court has previously recognized that Unocal review stems from a desire to check director action that disenfranchises shareholders. ${ }^{81}$ For instance, in its 1995 In re Santa Fe Pacific Corp. Shareholders Litigation ${ }^{82}$ opinion, the Delaware Supreme Court articulated why voting impairment should trigger enhanced scrutiny. "Board action which coerces stockholders to accede to a transaction to which they otherwise would not agree is problematic.... Thus, enhanced judicial scrutiny of Board action is designed to assure that stockholders vote . . in an atmosphere free from undue coercion." 83

In the recent Omnicare decision, the Delaware Supreme Court expanded upon this point, stating:

${ }^{79}$ Unocal Corp. v. Mesa Petroleum Corp., 493 A.2d 946, 955 (Del. 1985) (requiring directors to reasonably believe that there is a "danger to corporate policy and effectiveness" and that any defensive measure taken is "reasonable in relation to the threat posed").

${ }^{80}$ See, e.g., In re NCS Healthcare, Inc. S'holders Litig., 825 A.2d 240, 261-63 (Del. Ch. 2002) (upholding director action under the Unocal standard of reasonableness where there had been a shareholder vote), rev'd sub nom Omnicare, Inc. v. NCS Healthcare, Inc., 818 A.2d 914 (Del. 2003); Ace Ltd. v. Capital Re Corp., 747 A.2d 95, 108 (Del. Ch. 1999) ("[A] no-escape merger agreement that locks up the necessary votes [may constitute] an unreasonable preclusive and defensive obstacle within the meaning of Unocal."); Phelps Dodge Corp. v. Cyprus Amax Minerals Co., Nos. 17398, 17383, 17427, 1999 WL 1054255, at *3 (Del. Ch. Sept. 27, 1999) (noting but not deciding a claim that the termination fee probably violated Unocal standards); see also Strine, supra note 28, at 942 (concluding that judicial emphasis on stockholder choice includes deference to directors' proposals).

${ }^{81}$ See Unitrin, Inc. v. Am. Gen. Corp., 651 A.2d 1361, 1379 (Del. 1995) (discussing how Unocal review is intended to protect shareholders' franchise, and thus, corporate democracy).

${ }_{83}^{82}$ In re Santa Fe Pac. Corp. S'holders Litig., 669 A.2d 59 (Del. 1995).

${ }^{83}$ Id. at 68 . Conversely, the court has recognized-and should extend this recognition to all mergers in which disinterested shareholders hold controlling veto power-that the Unocal form of judicial review is limited to director action that is unilateral and not dependent upon concurrent, or subsequent, shareholder approval. See Williams v. Geier, 671 A.2d 1368, 1377 (Del. 1996) (“A Unocal analysis should be used only when a board unilaterally . . . adopts defensive measures in reaction to a perceived threat." (emphasis added)). 
The Delaware corporation statute provides that the board's management decision to enter into and recommend a merger transaction can become final only when ownership action is taken by a vote of the stockholders. Thus, the Delaware corporation law expressly provides for a balance of power between boards and stockholders which makes merger transactions a shared enterprise and ownership decision. Consequently, a board of directors' decision to adopt defensive devices to protect a merger agreement may implicate the stockholders' right to effectively vote contrary to the initial recommendation of the board in favor of the transaction. $^{84}$

In this respect, Omnicare was absolutely consistent with the arguments made in this Section. In determining whether to apply enhanced scrutiny, however, passage of control in the merger should make no difference at all. In Omnicare, the court determined that deal protection measures triggered enhanced scrutiny, despite its assumption that the business judgment rule applied to the directors' decision to approve the merger itself. ${ }^{85}$ Thus, the court's reaffirmation of the distinction between control-shifting mergers and other mergers ${ }^{86}$ was mere dictum. If shareholder approval is unimpaired by the unilateral director approval of deal protection devices, there should be no occasion for enhanced judicial scrutiny, even if the merger is one in which

${ }^{84}$ Omnicare, 818 A.2d at 930 . In Omnicare, the Delaware Supreme Court identified improper director motivation as a basis for enhanced scrutiny of deal protection measures that impaired shareholder voting rights. Id. The court held that "conflicts of interest arise when a board of directors acts to prevent stockholders from effectively exercising their right to vote contrary to the will of the board." Id. Reiterating this conflict of interest theme, the court further pronounced that " $[t]$ here are inherent conflicts between a board's interest in protecting a merger transaction it has approved, the stockholders' statutory right to make the final decision to either approve or not approve a merger, and the board's continuing responsibility to effectively exercise its fiduciary duties at all times after the merger agreement is executed." $I d$. These allusions to improper director motivation may be unfortunate. Though the court could have comfortably insisted upon enhanced scrutiny based solely on the perceived impairment of shareholder voting rights, as urged above, the arguably unnecessary invocation of improper director motivation may have contributed to a dissenting justice's concern that the majority opinion inappropriately "shamed" the defendant directors. Id. at 948 (Steele, J., dissenting). Enhanced scrutiny should not inherently depend upon an assumed or identified improper director motivation, particularly if such an assumption called into question the application of exculpatory charter provisions under statutes like section 102(b)(7) of the Delaware General Corporation Law. DEL. CODE ANN. tit. 8, § 102(b)(7) (2001) (limiting the personal liability of directors for breach of fiduciary duty as directors). See infra note 94 and accompanying text for a discussion regarding director liability and judicial scrutiny.

${ }^{85}$ Omnicare, 818 A.2d at 929.

${ }^{86} I d$. 
control changes. ${ }^{87}$ Conversely, even if the transaction is a stock-forstock merger without a change of control, unilateral director action that significantly impairs the shareholders' ability to effectively exercise their power to vote on the merger should be evaluated under Unocal/Unitrin proportionality standards. This is because the shareholder interests at stake appear, in light of the previously reviewed data, ${ }^{88}$ to be as financially significant as they are in change of control mergers.

This equivalence of doctrinal treatment does not ignore the significance of change of control. When engaging in proportionality review, a court could consider that the challenged merger involves a change of control-a significant fact that could call for a higher level of justification than might otherwise be required. The Unocal/Unitrin test is certainly flexible enough to accommodate such concerns, and accordingly, change of control need not require the construction and application of independent systems of doctrinal review.

What constitutes significant impairment of shareholder voting rights, for purposes of the proposed (or already extant) test, is of course a debatable question that, in all likelihood, will evolve with experience. For now, certain deal protection measures-two to three percent breakup fees or no-shop clauses with fiduciary outs, for example-are widely viewed as so prevalent and minimally intrusive upon shareholder voting rights that they may be insufficient, standing alone, to warrant enhanced judicial scrutiny. ${ }^{89}$ On the other hand,

${ }^{87}$ This approach, thus, elevates the significance of the shareholder franchise above other considerations in determining the standard of review by which courts are to assess the validity of deal protection devices. For this reason, this approach is somewhat different in emphasis than the useful and flexible catalogue of considerations identified in Gregory V. Varallo \& Srinivas M. Raju, A Fresh Look at Deal Protection Devices: Out from the Shadow of the Omnipresent Specter, 26 DEL. J. CORP. L. 975 (2001).

${ }^{88}$ See text accompanying notes $18-19$ (presenting empirical observations about the effect of voting rights on merger premium).

${ }^{89}$ See, e.g., McMillan v. Intercargo Corp., 768 A.2d 492, 498, 505 (Del. Ch. 2000) (describing a $3.5 \%$ termination fee as "still within the range that is generally considered reasonable"); Matador Capital Mgmt. Corp. v. BRC Holdings, Inc., 729 A.2d 280, 291 (Del. Ch. 1998) (finding that defensive measures including a no-shop provision and a termination fee do not trigger enhanced judicial scrutiny because they do not prevent a third party from making a bona fide offer at a higher price); In re Vitalink Communications Corp. S'holders Litig., No. 12085, 991 Del. Ch. LEXIS 195, at*19-20 (Del. Ch. Nov. 8, 1991) (declaring that a termination fee valued at approximately $1.9 \%$ of the total value of the transaction was not significant enough to prevent a full canvass of the market); Gregory V. Varallo \& Srinivas M. Raju, A Process Based Model for Analyzing Deal Protection Measures, 55 Bus. LAW. 1609, 1613 n.9 (2000) (citing cases in which breakup or termination fees ranging from $3-3.5 \%$ of transaction value were held to be reasonable and valid). Similarly, courts sometimes acknowledge conflicts of interest 
highly unusual and intrusive deal protection measures-such as crown jewel asset options at strike prices substantially below asset value or no-shop provisions that extend for a substantial time after termination-clearly call for proportionality review. ${ }^{90}$ In the middle of this spectrum, enhanced judicial scrutiny should not unduly trouble directors (or their counsel) who negotiate and plan merger transactions in good faith, since proportionality review is not without considerable deference (some might say too much deference) to director decisions. ${ }^{91}$ Moreover, enhanced judicial scrutiny, activated solely by an intrusion upon the voting rights of shareholders and not otherwise complicated by conflicts of director interest or bad faith, should not result in any individual director liability, given the almost universal adoption of exculpatory charter provisions."

There are several significant virtues of this suggested approach to selecting the appropriate mode of judicial review. First, it flows from, and applies to, director action-action impairing shareholder veto

on the part of directors, but find them insufficiently significant to warrant the more stringent "entire fairness" review that such conflicts would otherwise engender. See, e.g., Cinerama, Inc. v. Technicolor, Inc., 663 A.2d 1156, 1170 (Del. 1995) (agreeing with the.court of chancery that the "alleged hope of better employment opportunities" was insufficient to create a material conflict of interest); Unocal Corp. v. Mesa Petroleum Co., 493 A.2d 946, 958-59 (Del. 1985) (holding that no disqualifying self-interest was apparent when the corporation's self-tender would harm a stockholder bidder, while modestly benefiting all other stockholders, including directors).

${ }^{90}$ See, e.g., Mobil Corp. v. Marathon Oil Co., 669 F.2d 366, 375 (6th Cir. 1981) (finding that the crown jewel asset option granted to a bidder significantly dampened the interest of other potential bidders in the tender offer market and therefore was an unlawful, manipulative act in connection with a tender offer); Paramount Communications Inc. v. QVC Network Inc., 637 A.2d 34, 49-50 (Del. 1994) (classifying a stock option agreement with note payment and put features valued at $\$ 500$ million as draconian); Revlon, Inc. v. MacAndrews \& Forbes Holdings, Inc., 506 A.2d 173, 178 (Del. 1986 ) (invalidating an asset option at a strike price that was $\$ 100-\$ 175$ million below the value ascribed to the assets by the company's investment bank); First Union Corp. v. Suntrust Banks, Inc., No. 01-CVS-4486, 2001 WL 1885686, at *38 (N.C. Super. Aug. 10, 2001) (invalidating a nontermination clause extending five months after a shareholder vote as "an actionably coercive condition impeding the free exercise of the Wachovia shareholder's right to vote on the merger").

${ }^{91}$ See Strine, supra note 28 , at 942 (describing the "deference to directors" apparent when, in the course of a merger, courts allow directors to give preferred partners advantages over subsequent bidders).

${ }^{92}$ See Malpiede v. Townson, 780 A.2d 1075, $1094-95$ (Del. 2001) (finding that, absent "a loyalty violation or other violation falling within the exceptions to the [s]ection 102 (b) (7) exculpation provision," a director is not liable for his conduct in approving a merger); see also Alexander, supra note 78, at 906-07 (proposing a "vote coercion analysis" that operates independently of fiduciary considerations and allows for evaluation and invalidation of inappropriately coercive deal protection measures, without regard to director motivation or conduct). 
power-that increases shareholders' vulnerability to increased agency costs. This vulnerability is a core basis for judicial enforcement of fiduciary duties. ${ }^{93}$ It is entirely fitting, therefore, that as shareholders' ability to protect themselves from director action is diminished by the directors' own conduct, judicial review of such conduct becomes more active. Second, the objective reference to impairment of the shareholder franchise obviates difficult problems of proof in regard to assessing the subjective motivations of directors. ${ }^{94}$ Finally, it operates regardless of whether the transaction involves a change of control, and is applicable both to acquiring firm and target firm directors, since its focus is on the importance of the right to vote on a merger, regardless of whether that right belongs to the acquiring or target firm shareholders.

\section{Reassessing Standards of Conduct of Acquiring Firm Directors}

In the not too distant past, and perhaps even continuing today, the words "serial acquirer" have been the financial equivalent of "serial killer" in terms of the opprobrium they have connoted. ${ }^{95}$ In recent corporate scandals, the culprits seem to have come more from the ranks of growth-oriented acquirers than from entrenched managers seeking to retain corporate independence in the face of hostile bids. Although WorldCom, Global Crossing, and Tyco have given new life to concerns about acquirer hubris and empire building at the expense of the acquirer's shareholders, these concerns are hardly new. ${ }^{96}$ Such concerns are continually inflamed by reports that merger benefits to acquiring firm shareholders are skimpy or even negative, while

93 See D. Gordon Smith, The Critical Resource Theory of Fiduciary Duty, 55 VAND. L. REV. 1399, 1404 (2002) (noting that "the beneficiary's vulnerability emanates from an inability to protect against opportunism by the fiduciary"); Eric Talley, Taking the "I" Out of "Team": Intra-Firm Monitoring and the Content of Fiduciary Duties, 24 J. CORP. L. 1001,1003 (1999) (pointing out that one of the main purposes of fiduciary law is to deter intrafirm opportunism).

${ }^{94}$ See Black \& Kraakman, supra note 19, at 565 (questioning the utility of a standard of review focusing on the directors' "primary purpose," rather than on "the effect of the board's actions").

${ }^{95}$ See, e.g., Dave Beal \& Fred Zimmerman, Merger Mess, DAILY DEAL, Aug. 21, 2002, available at http://www.thedeal.com; There's No Magic in Mergers, Bus. WK., Oct. 14, 2002, at 178 [hereinafter No Magic] (discussing the destruction of shareholder wealth caused by the "gigantic wave of mergers and acquisitions" during the 1990s).

${ }^{96}$ See supra notes 4, 13 (noting that negative postmerger returns are often received by the acquiring firms' shareholders). 
such benefits disproportionately accrue to target firm shareholders. ${ }^{97}$ The inevitable questions, therefore, are whether the applicable legal structure overprotects the interests of target firm shareholders while underprotecting the interests of acquiring firm shareholders, and whether the standards of judicial review of the conduct of the acquiring firm's directors should be adjusted. ${ }^{98}$

There is surely something anomalous in the way that corporate law deals with the duties of acquiring firm directors relative to those of the target firm. Fiduciary duties presumably respond to and address, at least in part, concerns over vulnerability to agency costs. Therefore, one might expect those duties to be most aggressively defined and enforced where concerns over such vulnerability are the greatest. ${ }^{99}$ It is not clear, however, that in stock-for-stock mergers, or even in mergers generally, target firm shareholders are more vulnerable to director misbehavior than acquiring firm shareholders.

Most significant in this comparative assessment is the statutory treatment of target shareholders relative to acquirer shareholders in the allocation of voting and appraisal rights. Target firm shareholders are invariably entitled under state law to vote on mergers, ${ }^{100}$ a fact that ought to provide a highly meaningful, even if imperfect, check on director misbehavior on the target side. Delaware law provides even greater protection, in the form of appraisal rights, for target shareholders where the merger consideration includes cash. ${ }^{101}$ Acquiring firm shareholders, in contrast, rarely, if ever, have such rights under state law. Even when the acquirer issues a huge percentage of its shares in the merger, state law generally vests the decisive voting power over the transaction in the hands of the board of directors alone. ${ }^{102}$ It is only by virtue of stock exchange rules that large stock

${ }^{97}[\mathrm{~T}]$ he vast majority of investors suffered dearly for the sin of investing in companies that had merger fever....

The only real winners were shareholders of target companies who sold their stock within the first week of the takeover. ...

... [Acquirers] overestimated the gains of the cost-cutting and synergies the mergers would bring.

No Magic, supra note 95; see also Andrade et al., supra note 1, at 112 (comparing the announcement-period abnormal returns for target and acquirer firms).

${ }_{98}$ For a relatively early effort to deal with this balance, see Coffee, supra note 13.

${ }^{99}$ See sources cited, supra note 93 (discussing the inability of vulnerable parties to protect themselves from fiduciary opportunism).

${ }^{100}$ MODEL BUS. CORP. ACT ANN. $\$ 11.04$ (Supp. 2002).

${ }^{101}$ Del. Code ANN. tit. 8, § 262(b) (2) (2001).

${ }^{102}$ Even where the acquirer issues more than twenty percent of its shares in a merger, the transaction is commonly structured as a triangular or reverse triangular 
issuances in connection with mergers come to require acquirer shareholder approval. ${ }^{108}$

The judicial treatment of fiduciary duties is itself somewhat asymmetrical. The courts are quite willing, perhaps appropriately, to discern an "omnipresent specter" of self-interest when directors take action that tends to protect their corporate positions from threats to their continued control, and to derive from that "specter" a greater judicial willingness to inquire into the directors' conduct. ${ }^{104}$ It is not preposterous, at least, to identify a similar "specter" as a motivation for acquiring firm managers whose positions, and perhaps compensation, will be substantially enhanced postmerger, and to reject such a "specter" with respect to target directors, whose approval of a merger will result, not in the preservation, but in the loss of their positions. ${ }^{105}$

merger with an acquisition subsidiary of the acquirer, thereby avoiding any state law voting requirement for the acquirer's shareholders. See MELVIN ARON EISENBERG, CORPORATIONS AND OTHER BUSINESS ORGANIZATIONS: CASES AND MATERIALS 1099 (8th ed. 2000) (explaining how conventional triangular mergers operate). The California corporate statutes provide a rare exception to this voting rights structure requiring a vote of shareholders of the acquiring firm "whose equity securities are issued, transferred, or exchanged in the reorganization." CAL. CORP. CODE $\$ \$ 1200(\mathrm{e})$, 1201 (a) (West 2003).

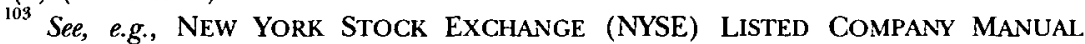
$\$ 312.03$ (c), available at http://www.nyse.com (requiring shareholder approval prior to the issuance of twenty percent or more of the voting power of the stock).

${ }^{104}$ See Unocal Corp. v. Mesa Petroleum Co., 493 A.2d 946, 954 (Del. 1985) (recognizing that, because a board may act in its own self-interest, there is a duty of judicial examination before the protections of the business judgement rule are granted). Whether the courts have adequately used such willingness is a source of continuing debate. See, e.g., Ronald J. Gilson, Unocal Fifleen Years Later (and What We Can Do About It, 26 DEL. J. CORP. L. 491, 491 (2001) (discussing the evolution of Unocal into an "inexplicable preference that control contests be resolved through elections rather than through market transactions"); Jeffrey N. Gordon, "Just Say Never?" Poison Pills, Deadhand Pills, and Shareholder-Adopted Bylaws: An Essay for Warren Buffett, 19 CARDOzO L. REV. 511, 525 (1997) (noting the increased judicial deference given to board decisions in Unitrin, as compared to that granted in Unocal); Martin Lipton \& Paul K. Rowe, Pills, Polls and Professors: A Reply To Professor Gilson, 27 DEL. J. CORP. L. 1, 1 (2002) (defending the choices made by Delaware courts since Unocal was decided); Paul L. Regan, What's Left of Unocal?, 26 DEL. J. CORP. L. 947, 947 (2001) (arguing that the Delaware Supreme Court's use of "substantive coercion" has weakened shareholder power and reduced the level of Unocal review).

${ }^{105}$ See, e.g., Alexander, supra note 78, at $901 \mathrm{n} .15$ (describing a "typical merger" as one in which "few, if any, of the directors of the target will have continuing positions with the merged company"); John C. Coates IV, Measuring the Domain of Mediating Hierarchy: How Contestable Are U.S. Public Corporations?, 24 J. CORP. L. 837, 858-59 (1999) (pointing out that even in friendly mergers, most directors of the target company will lose control of the organization); see also Black \& Kraakman, supra note 19, at 536 (positing without explication that target directors who "will likely lose their positions ... face a strong conflict of interest"). While severance benefits might well induce such 
These considerations suggest that, in a friendly stock-for-stock merger, the acquirer's directors' decisions should be at least as, if not more, suspect and deserving of judicial inquiry as the decisions of the target directors. ${ }^{106}$ Yet, it is target firm directors who are overwhelmingly the object of shareholder litigation, premised on a breach of fiduciary duty and an asserted failure to obtain otherwise available value for the shareholders. ${ }^{107}$ By contrast, the acquirer's directors are rarely the focus of shareholder litigation that claims the acquiring firm is paying too much. ${ }^{108}$ If fear of litigation and liability elicits care at all, one would expect target firm directors to be far more motivated than acquiring firm directors to secure financial and legal advisors and to make decisions that will withstand judicial review.

directors to favor a merger for personal reasons, it is hard to understand how that motivation would systematically conflict with the goal of achieving the best deal available, when the corporation will disappear as a publicly traded firm in any scenario.

${ }^{106}$ See William T. Allen et al., The Great Takeover Debate: A Meditation on Bridging the Conceptual Divide, 69 U. CHI. L. REv. 1067, 1077 n.25 (2002) (asserting that "entity school advocates should be spending more time ensuring that the stockholders of acquirers have comparable protections under state corporation law (for example, the right to approve by vote a wider class of acquisitions)").

107 See Martin Lipton, Pills, Polls, and Professors Redux, 69 U. CHI. L. REv. 1037, 1051 n.54 (2002) (arguing that target directors are "frequently overly optimistic" about friendly acquisitions, but more circumspect about unsolicited takeover bids because of the fear of litigation-so the judicial suspicion of directors in a hostile deal is misplaced).

${ }^{108}$ Given the formidable obstacles to establishing a claim of a waste of corporate assets, it is hardly surprising that this claim has not been advanced often, if ever, to challenge acquirer director action. See Allen et al., supra note 31, at 1317-18 (noting that "no Delaware case of which [the authors] are aware has ever held that a properly ratified transaction constituted waste"). In rare cases, to be sure, acquirer shareholders do sue for relief against acquisitions. Paramount Communications, Inc. v. Time, Inc., 571 A.2d 1140, 1140 (Del. 1989), was one such rare case. In that case, the court rejected the claim that Revlon required Time's directors to seek higher value for the shareholders. Id. at 1142 . The doctrinal hook that triggered something more than cursory judicial review was the fact that the restructured deal with Warner responded to an unsolicited tender offer by Paramount and, thus, triggered enhanced scrutiny under Unocal. Id. at 1151-55. It is a relatively disregarded fact that Warner shareholders also brought suit in connection with the merger with Time, asserting the more conventional claim of a breach of fiduciary duty by the target (Warner) directors. Id. at 1142; see also Silverstein v. Warner Communications, Inc., No. 11285, 1991 Del. Ch. LEXIS 15, at $* 2-3$ (Del. Ch. Feb. 4, 1991) (discussing actions brought on behalf of former Warner shareholders in the aftermath of the Time merger). Even in the recent litigation surrounding the HP/Compaq merger, in which the most visible litigation was initiated by a shareholder of the acquirer, the claims centered on voting manipulation through vote-buying and nondisclosure, rather than on substantive failures by the directors to negotiate the best deal. Hewlett v. Hewlett-Packard Co., No. 19513, 2002 WL. 818091 , at $* 1$ (Del. Ch. Apr. 30, 2002). Indeed, Hewlett-Packard's directors were not even named as defendants in the litigation. Id. 
This observation should not be taken as a plea for enhanced judicial scrutiny of the conduct of acquiring firm directors in every acquisition. Extending such scrutiny to every acquisition-including direct or triangular mergers, asset purchases, or other forms-would do considerable violence to traditional principles of judicial respect for director action. ${ }^{109}$ In fact, one could, perhaps more persuasively, suggest that the corporate law's tolerance (in the form of business judgment rule deference) of acquiring firm director behavior requires similar judicial tolerance of target firm director behavior, or at least for a more circumspect application of principles of enhanced judicial scrutiny.

${ }^{109}$ Business judgment rule deference to the actions of acquiring firm directors, operating within their sphere of statutory authority, has accounted for judicial approval of acquisitions seen as imprudent, if not outrageous, by financial and academic commentators. For example, in Time-Wamer, in which then Chancellor Allen, with lucidity impressive even by his own lofty standards, explained:

Reasonable persons can and do disagree as to whether it is the better course from the shareholders' point of view collectively to cash out their stake in the company now at this (or a higher) premium cash price [offered by Paramount]. However, there is no persuasive evidence that the board of Time has a corrupt or venal motivation in electing to continue with its long-term plan even in the face of the cost that that course will no doubt entail for the company's shareholders in the short run. In doing so, it is exercising perfectly conventional powers to cause the corporation to buy assets for use in its. business. Because of the timing involved, the board has no need here to rely upon a self-created power designed to assure a veto on all changes in control.

The value of a shareholder's investment, over time, rises or falls chiefly because of the skill, judgment and perhaps luck-for it is present in all human affairs - of the management and directors of the enterprise. When they exercise sound or brilliant judgment, shareholders are likely to profit; when they fail to do so, share values likely will fail to appreciate. In either event, the financial vitality of the corporation and the value of the company's shares is in the hands of the directors and managers of the firm. The corporation law does not operate on the theory that directors, in exercising their powers to manage the firm, are obligated to follow the wishes of a majority of shares. In fact, directors, not shareholders, are charged with the duty to manage the firm.

In the decision they have reached here, the Time board may be proven in time to have been brilliantly prescient or dismayingly wrong. In this decision, as in other decisions affecting the financial value of their investment, the shareholders will bear the effects for good or ill. That many, presumably most, shareholders would prefer the board to do otherwise than it has done does not, in the circumstances of a challenge to this type of transaction, in my opinion, afford a basis to interfere with the effectuation of the board's business judgment.

Paramount Communications Inc. v. Time Inc., Nos. 10866, 10670, \& 10935, 1989 WL 79880, at *30 (Del. Ch. July 14, 1989), affd, 571 A.2d 1140 (Del. 1989) (citations omitted). 
Alternatively, the evident, and not readily justifiable, disparity between the treatment in mergers of acquiring firm shareholders and target firm shareholders invites alteration of the statutory voting framework governing mergers. The drafters of the Model Business Corporation Act have already taken a step in this direction, by following the stock exchange rules, and revising the model statute to provide for a shareholder vote whenever more than twenty percent of the corporation's stock is to be issued (in a merger or otherwise). ${ }^{110}$ Even this requirement, however, has a less demanding constraint than most, if not all, state merger statutes (which require approval by at least a majority of the outstanding shares entitled to vote-as opposed to the "more yes votes than no votes" standard now embraced in the Model Act)." Moreover, nothing in the Model Act even begins to impose an acquiring firm shareholder vote requirement with respect to an acquisition not involving the issuance of stock. Given the evident imbalance in the aggregate benefits of mergers and acquisitions, perhaps this statutory imbalance merits reconsideration.

\section{CONCLUSION}

The scope and purpose of this Article are thus quite modest. Preliminary data suggest that premiums in cash mergers and stock-forstock mergers do not differ substantially, but that the voting right of shareholders (at least acquiring firm shareholders) in a merger has significant value. The rough equivalence of premiums reinforces doubts about the utility of change of control as a touchstone for determining the appropriate level of judicial review of director action in the merger context. The financial significance of shareholder voting rights both reaffirms the desirability of judicial protection of such rights and suggests that substantial impairment of such rights by unilateral director action should occasion enhanced judicial scrutiny. Finally, because there is typically much less legal protection in mergers for shareholders of acquiring firms than for those of target firms-and because the evidence indicates that such mergers disproportionately benefit target shareholders-renewed thought should be

${ }^{110}$ MOdel BuS. CORP. ACT $\$ 6.21$ (f) (1) (ii) (1999); see also American Bar Association Committee on Corporate Laws, Changes in the Model Business Corporation Act-Fundamental Changes, 54 BuS. LAw. 685, 712 (1999) (including official comments elaborating on $\S 6.21(\mathrm{f})$ ).

111 Committee on Corporate Laws, supra note 110, at 713; $f$., DEL. CODE ANN., tit. $8, \S 251$ (c) (2001) (requiring target shareholder approval by at least a majority of the outstanding shares entitled to vote). 
devoted to whether, and how, the law could more evenly and consistently evaluate the conduct of acquirer and target directors. If the only aspect of state corporate law that distinguishes acquirers and targets in stock-for-stock mergers is that the target's shareholders vote on the deal and the acquirer's shareholders do not, perhaps the courts' only choice or obligation is to protect such voting rights where they are afforded, but otherwise treat both sets of directors identically. 


\section{APPENDIX A}

The tables below are calculations based upon information derived from public announcements and SEC filings in connection with mergers announced in the years 1999 through 2002. The sample included 81 mergers in which the consideration was entirely cash and 97 mergers in which the consideration was entirely stock of the acquiring corporation.

Table 1: Comparison of Premiums in Cash and Stock Mergers

\begin{tabular}{|c|c|c|}
\hline $\begin{array}{c}\text { Form of } \\
\text { consideration }\end{array}$ & $\begin{array}{c}\text { Mean premium } \\
\text { (standard } \\
\text { deviation) } \\
(\%)\end{array}$ & $\begin{array}{c}\text { Median } \\
\text { premium } \\
(\%)\end{array}$ \\
\hline Cash (N=81) & $35.92(31.24)$ & 28.07 \\
\hline Stock $(\mathrm{N}=97)$ & $30.09(37.97)$ & 28.26 \\
\hline $\mathrm{t}$ & -1.12 & \\
\hline
\end{tabular}

Table 1 compares the mean and median premiums in cash versus stock-for-stock mergers. The table also reflects the standard deviations (which are relatively large in relation to the means, indicating a broad dispersion of premiums in both cash and stock-for-stock mergers), and the result of a least-squares regression of the effect of the form of merger consideration on premium size. On the limited data analyzed, that result fails to establish any statistically significant effect on mean or median premium size of the use of cash rather than stock as merger consideration. 
Table 2: Effects of Selected Variables on Size of Premium (stock-for-stock mergers only $(N=97)$ )

\begin{tabular}{|c|c|c|c|}
\hline Premium & Coefficient & T & \\
\hline \hline $\begin{array}{c}\text { Voting } \\
\text { right }\end{array}$ & -18.65 & -2.04 & \\
\hline $\begin{array}{c}\text { T directors } \\
\text { Revenue } \\
\text { indicator }\end{array}$ & -0212 & 0.10 & \\
\hline & & -1.45 & \\
\hline
\end{tabular}

Table 2 reflects the results of a least-squares regression of the effects on premium size (percentage measured by the announced exchange ratio and closing prices of acquirer and target corporation shares on the day preceding announcement of the transaction) of the variables (i) "voting rights," i.e. whether acquiring shareholders were entitled to vote on the proposed merger, either under state corporate law or stock exchange rules); (ii) "T directors," i.e. the percentage of directors of the postmerger firm who were directors or officers of the target; and (iii) "revenue indicator," a variable measured by an indicator equaling 1 if the ratio of acquiring firm revenues to target firm revenues was 5 or greater, 0 if otherwise. The cut-off ratio of 5 was found by a grid search on which 5 was the value that maximized the equation's explanatory power. 


\section{APPENDIX B}

\section{Comparative Summary of Recommendations}

\begin{tabular}{|c|c|c|c|}
\hline Topic & Black \& Kraakman & Kahan & Hamermesh \\
\hline $\begin{array}{l}\text { Standard of review } \\
\text { dependent on } \\
\text { change of control }\end{array}$ & Eliminate $^{112}$ & Accepted in general ${ }^{1 / 3}$ & Eliminate $^{114}$ \\
\hline Scope of Revlon & Apply to all mergers ${ }^{115}$ & $\begin{array}{l}\text { Apply to change of } \\
\text { control mergers }\end{array}$ & $\begin{array}{c}\text { Eliminate as a } \\
\text { distinct standard }\end{array}$ \\
\hline $\begin{array}{l}\text { Review of deal } \\
\text { protection } \\
\text { measures }\end{array}$ & $\begin{array}{l}\text { Continue trend toward } \\
\text { fiduciary duty limits }\end{array}$ & $\begin{array}{c}\text { Generally not separately } \\
\text { addressed }^{119}\end{array}$ & $\begin{array}{l}\text { Limit by applying } \\
\text { enhanced } \\
\text { scrutiny }\end{array}$ \\
\hline $\begin{array}{l}\text { Acquirer share- } \\
\text { holders vote }\end{array}$ & Adopt $^{191}$ & Not addressed & Consider $^{122}$ \\
\hline
\end{tabular}

${ }^{112}$ See Black \& Kraakman, supra note 19, at 534-36, 538 ("[C]ourts should avoid second-guessing business decisions, and shareholders who are unhappy with the board's actions should look to proxy contests rather than the courts to press their claims.").

${ }^{113}$ See Kahan, supra note 29, at 593-99 (analyzing directors' Revlon duties upon sale of company). But see id. at $597 \mathrm{n} .84$ (suggesting a more lenient standard of review for change of control mergers not subject to deal protection measures).

${ }^{114}$ See supra Part III.A (criticizing application of enhanced judicial scrutiny because of a change of control transaction).

${ }^{115}$ See Black \& Kraakman, supra note 19, at 543-45 (arguing that stock-for-stock mergers between a large company and a small one should be reviewed under Revlon).

${ }^{116}$ See Kahan, supra note 29 , at 597-98 (contending board decisions in a change of control, which cannot be reversed by shareholders, should undergo heightened scrutiny).

117 See supra Part III.B (arguing that Revlon does not impose substantive duties on directors that prior cases did not already articulate).

${ }^{118}$ See Black \& Kraakman, supra note 19 , at 546-47 (exploring why case law restricts use of defensive measures for cash and for equity bids).

119 But see Kahan, supra note 29, at $597 \mathrm{n} .84$ and note 113 (presenting view that Unocal standard, and not the Revlon standard, should apply whenever a "board entered a merger agreement which, if approved, would result in a change of control but which is not protected by such defensive measures as a poison pill").

${ }^{120}$ See supra Part III.C (proposing that Unocal proportionality standard of review apply whenever director action "significantly impairs" shareholder voting rights).

${ }_{21}$ See Bernard Black \& Reinier Kraakman, A Self-Enforcing Model of Comporate Law, 109 HARV. L. REV. 1911, 1953-55 (1996) (recommending, in the context of laws governing emerging economies, that default rules should include requiring a shareholder vote on acquisitions of assets, directly or through subsidiaries, of over fifty percent in book value of the corporation's assets).

${ }^{122}$ See supra Part III.D (suggesting that enhanced judicial scrutiny may be necessary to protect acquiring firm's shareholders from directors motivated to engage in aggressive acquisitions). 
* 